How to cite this article:

Shukri, S. (2019). Combatting terrorism at Sea: Assessing NATO'S maritime operations in the Mediterranean. Journal of International Studies, 15, 105-116.https:// doi.org/10.32890/jis2019.15.7

\title{
Combatting Terrorism at Sea: Assessing NATO'S Maritime Operations in the Mediterranean
}

\author{
Shazwanis Shukri \\ School of International Studies, \\ Universiti Utara Malaysia, Malaysia \\ shazwanis@uum.edu.my \\ DOI: https://doi.org/10.32890/jis2019.15.7 \\ Received: 7/7/2019 Revised: 29/12/2019 Accepted: 30/12019 \\ Published: $31 / 12 / 2019$
}

\begin{abstract}
Terrorism via the Mediterranean Sea route is one of the security threats faced by Europe in recent years. The basin recorded a large volume of maritime vessels traversing daily via the major straits and consequently exposed them to the possibility of terrorist attacks. This includes cargo and commercial vessels that carry tons of valuable cargo. There is growing concern that the vessels may be used to support terrorist activities. In light of this, NATO has adopted maritime operations to strengthen sea-patrolling and enhance the security of sea lanes in the Mediterranean. This paper sought to examine the terrorist incidents that occurred in the Mediterranean Sea. The paper then scrutinized the evolution of NATO's approaches to combat terrorism in the basin from 2001 until 2016. Specifically, this paper analysed the implementation of the Operation Active Endeavour (OAE) which was initiated as an immediate response to the 9/11 terrorist attacks in the United States to fight against international terrorism. The mandate assigned through this operation includes, amongst others, monitoring and surveillance activities, escorting assistance, compliant boarding and joint-training with NATO partners. These tasks have significantly contributed to a sharp decline in terrorist plots in the Mediterranean Sea. This paper obtained its data from textual analysis and interviews with NATO military officers. The results conclude that maritime operations by NATO play a functional role to hinder the potential of terrorist attacks and effectively maintain the security of the sea lanes.
\end{abstract}

Keywords: NATO, maritime security, maritime terrorism, Mediterranean Sea, Operation Active Endeavour. 


\section{Introduction}

Maritime threat has become ever complicated due to the growing speculation of the convergence between maritime terrorism and piracy. The similar characteristics of maritime terrorism and piracy increase the speculation that a nexus could emerge between these two threats. Maritime terrorism incidents are relatively less significant than land-based incidents due to the lower number of attacks, and also no attacks occurred for some years. The number of incidents only represent a small percentage of overall terrorist attacks. However, past incidents have recorded several atrocious incidents involving terrorists at sea which remain controversial until the present day. Today, maritime terrorism has become one of the most pressing issues that require the highest level of cooperation among the security actors in the maritime domain. Terrorist groups aim at specific targets, both military and economic, to jeopardise the security of maritime chokepoint (Snoddon, 2007). The operation of maritime vessels which carry tons of valuable cargo, namely the world's oil and gas, as well as liquefied natural gas (LNG) tankers offer attractive targets, particularly, of economic terrorism (Roy, 2008). Despite the infrequency of the attacks, the possibility of terrorist attacks against the maritime domain should not be eliminated given the history of a few previous appalling attacks that have taken place.

Over the past decade, the Mediterranean Sea has become a target for terrorist groups which aimed the attacks on the commercial vessels and other maritime activities including oil rigs and harbours. This has become a great challenge for European countries, particularly after the 9/11 incidents. The 9/11 terrorist attacks caught the attention of the Western media and raised awareness of the emergence of terrorist groups launching a series of attacks directed at the states. NATO has declared terrorism as one of the threats the European states are confronted with, which require greater attention and responses to tackle the issue. In 2001, NATO responded immediately following the terrorist attack in the United States by initiating its naval mission, namely Operation Active Endeavour (OAE).

This paper investigates the expansion and development of the NATO initiatives that have been enforced to combat terrorist threats in the Mediterranean Sea. The analysis is twofold. First, this study delves into the overview of terrorist attacks reported in the Mediterranean. The second part concentrates on the advancement of maritime operations implemented by NATO to address the issue and simultaneously combat terrorism. The study adopted the qualitative research method for data collection and data analysis. The study utilised a range of data including official policies, legislative documents, and official reports of NATO in relation to anti-terrorism missions. In addition, data was also mainly obtained from literature analysis and publications of other scholars. The study also involved elite interviews with NATO military officials pertaining to the said issue to complement information gathered from primary and secondary documents.

\section{Literature Review}

The plethora of the security challenges faced by the Euro-Mediterranean area has always been associated with turmoil and instability in the region. These include illegal migration, 
inter-state conflicts, failed states and terrorism which have become a source of instability in the area. These threats have significantly posed a threat not only on land, but also with growing numbers of security incidents at sea. Numerous regional security initiatives have been launched by main security actors in the region, particularly NATO and the European Union (EU).

Calleya, in his work, Security Challenges in the Euro-Med Area in the $21^{\text {st }}$ Century: Mare Nostrum (2013) explains how NATO, as one of the traditional actors in the region has continually undertaken security operations to preserve the security in the region, on land and at sea. NATO has rigorously conducted security operations in the region to demonstrate not only their commitment in preserving the stability of the region, but also to preserve their own security interests in the area. Calleya stressed how geographical proximity in the Mediterranean may affect the situation between the states of the region. For instance, political turmoil in Africa may significantly affect the stability in Spain or Italy, particularly with the emergence of terrorist groups operating on land and also in the maritime domain. Calleya highlighted the policies formulated by NATO to address the security threats faced by the Euro-Mediterranean states, and the security initiatives proposed to enhance closer relations with its partners. These included, the Mediterranean Forum and the Euro-Mediterranean Partnership (Calleya, 2013).

Martin Fink, in his work, Maritime Interception and the Law of Naval Operations (2018) examined maritime the interception operations adopted by NATO in the fight against international terrorism. Fink explored the military operations mounted by NATO after the 9/11 terrorist attacks in the United States. These included the Operation Enduring Freedom (OEF) and the Operation Iraqi Freedom (OIF). According to Fink, these two efforts were initiated by NATO as naval operations in support of the United States to fight and combat terrorism. OEF was launched to combat maritime terrorism in Afghanistan from the sea. The operation aimed to detect, deter and disrupt terrorist plots, mainly to oust Taliban and alQaida from Afghanistan. For this operation, naval forces of NATO and its partners monitored movements around the Arabian Peninsula (Fink, 2018). Any unusual movements or events at sea were intercepted with strike and air support during the course of the operation. Fink also delved into another paramount military operation conducted by NATO as a response to the 9/11 attacks to fight against terrorism. OIF commenced in 2003 as part of the efforts of NATO, the US and the UK to fight against Iraqi Armed Forces. This operation lasted until 2012 after the completion of major combats in Iraq.

According to Bruns and Krause, in their work, Routledge Handbook of Naval Strategy and Security (2016) the importance of the Mediterranean should not be underestimated. The Mediterranean Sea is the busiest waterway with several important chokepoints, including the Suez Canal and the Straits of Gibraltar. However, its geographical proximity to North Africa and the Middle East, which grapple with regional political crises and conflicts, has jeopardized maritime security in the Mediterranean. After the terrorist attacks of 9/11, international terrorism has become a headline and focal point for nation states, including 
terrorism within and from the maritime domain. The Mediterranean Sea has become more vulnerable to terrorist activities due to the numerous important maritime facilities such as harbours and oil platforms. Consequently, all these infrastructures could easily be exploited by the terrorist groups to launch their attacks.

Moreover, Bruns and Krause (2016) emphasized how terrorist groups have started to exploit merchant ships traversing the Mediterranean Sea as a weapon and platforms for attacks at sea. Such attacks would lead to major interference in the shipping operations in the Mediterranean Sea, as well as severely affect international trade. Bruns \& Krause argued that maritime terrorism is no novel phenomena. One of the infamous incidents reported at sea was the use of the merchant vessel, Baltic Sky, which was loaded with explosives and weapons, travelling across the Ionian Sea in 2003. Apart from attacking the vessels, this incident demonstrated the capability of terrorist groups to also use ships to carry bombs and detonators as part of their modus operandi at sea. This attack also demonstrated how terrorist groups have increasingly used maritime routes to disrupt and hamper the navigation of vessels at sea (Bruns \& Krause, 2016).

The escalation of maritime terrorism has urged maritime stakeholders in the Mediterranean to continually address this threat with various cooperation and counter-terrorism measures. Nevers, in her work, NATO's International Security Role in the Terrorist Era (2007) argued that NATO has played a major role in supporting the US to combat international terrorism. In response to the $9 / 11$ attack, NATO has been very active in conducting a defensive mission in the Mediterranean Sea (Nevers, 2007). The deployment of NATO naval forces in the Eastern Mediterranean has demonstrated its commitment to address the threat of terrorism more seriously than ever. The role of NATO in the US War on Terror includes intelligence sharing and enhancing surveillance activities for early detection of any potential attack. Through this mission, NATO has also increased its capabilities in technology and the patrolling system, including the use of NATO airborne warning and control systems (AWACS). However, the most significant effort undertaken by NATO was intelligence sharing regarding terrorist activities with numerous NATO and non-NATO partners. According to Nevers (2007), NATO has shown its commitment to continually intensify its efforts to tackle the terrorism threat. NATO has developed counterterrorism technologies, including the use of explosive devices to detect and attack aircraft used by the terrorist groups.

In sum, maritime terrorism is not novel, rather it started as early as the 1980s in which terrorist groups aimed to seek the attention of the international community and states. Other than terrorism, it can be observed that the Euro-Mediterranean region is also grappling with various instability including political crises and inter-state conflicts. All of these threats require greater attention from maritime stakeholders in the region, particularly NATO and EU. As traditional and key regional actors, NATO and EU have played vital roles in contributing to preserve the safety and security of the sea lanes of communication.

\section{Terrorist Attacks in the Mediterranean Sea}

The incidents of maritime terrorism first started in the early 1960s when the Palestinian insurgents launched their notorious attacks (Murphy, 2007). However, the most prominent 
case of maritime terrorism was the Achille Lauro incident. The cruise ship Achille Lauro was hijacked in the Mediterranean in 1985 and regarded as one of the most dreadful incidents involving terrorists at sea. Consequently, the hijacking raised great awareness among the international community about the real threat of terrorism in the maritime domain. The Popular Front for the Liberation of Palestine (PFLP) hijacked the cruise ship carrying more than 750 passengers off the coast of Egypt, en route from Alexandria to Ashdod (Johnson, 2007). More than 100 passengers on board including the crews of the vessel were taken as hostage (Snoddon, 2007). The hijacking took place as an attempt of PFLP to gain attention from the international community, particularly to coerce the Israel government to release 50 Palestinians who were in detention in Israel (Greenberg et al. 2006). However, the U.S. Navy aircraft from the aircraft carrier USS Saratoga operating in the basin successfully intercepted the airliner carrying the hijackers, forcing the plane to land in Italy (Kraska \& Pedrozo, 2013). The most dreadful impact resulting from the hijack was the murder of one of the passengers on board, Leon Klinghoffer. Consequently, the security measures taken at ports and aboard ships remain highly questionable whereby this incident resulted in a sharp decline in the Mediterranean cruise liner industry (Johnson, 2007).

After a long hiatus from any attacks, the recent escalation of terrorist attacks in Egypt's Sinai Peninsula has again made headlines in the media. On 16 July 2015, Islamic State militants claimed its fighters were responsible for destroying an Egyptian navy vessel using rockets in the Mediterranean Sea (Nightingale, 2015). The recent rise in attacks has raised questions about the security level and the safety of shipments in the Sinai peninsula despite the Egyptian security operations. The attack also demonstrated increased sophistication in the insurgents' tactics compared to their attack against the ship in the Suez Canal previously (Nightingale, 2015). The Islamic States of Iraq and Syria (ISIS) also took advantage of Libya's political instability to use the state as a gateway to Europe. The strategic location of Libya, which is just a few hundred miles away from the important gateways to Europe such as Sicily and Lampedusa, has increased the opportunity for the terrorists to access Europe easily from Africa (Martino, 2015).

Other than navy vessels and commercial ships, there is also a growing fear that the terrorist group may target fishing boats to launch their attacks. ISIS has released their propaganda to use Libya as a base to cause terror and chaos, and plan to sail across the Mediterranean Sea to hijack boats carrying immigrants from Libya. It is possible that another destructive act of terrorism may occur in the Mediterranean Sea after the notorious Achille Lauro attacks. ISIS has a large and significant support in Libya, showing the massive threat faced by European countries to control the possibility of terror attacks from the militants. The purported propaganda was treated as an unofficial propaganda of ISIS and has yet to be confirmed, however the international community, particularly the shipping companies expressed their fears that it may result in a major chaos in maritime shipping and navigation, including the possibility of using the hijacked vessel as a delivery platform for WMD (Joubert, 2013). The number of terrorist attacks at sea is considerably small than the land attacks, however with the rise of incidents involving ISIS has created fear of how this minor attack can cause major damage to maritime facilities. 


\section{NATO Counter-Terrorism Operations in the Mediterranean Sea}

NATO has expressed its commitment to combat terrorism following the $9 / 11$ and has included the Mediterranean Sea as part of the counter-terrorism initiative. Operation Active Endeavour (OAE) was mounted on 4 October 2001 as a prompt response for the $9 / 11$ attacks as part of NATO's contributions to fight international terrorism in one of the busiest trade routes in the world (Feldt, 2011). The operation was officially enforced on 26 October 2001. OAE was designed mainly with several important mandates. Under this operation, it operated in the eastern Mediterranean Sea whereby NATO ships patrolled the basin, monitored shipping routes and tracked ships while simultaneously conducting surveillance activities for any suspicious vessels traversing the Mediterranean Sea. In addition, NATO ships systematically carried out monitoring operations focusing on harbours, important passage and 'choke' points (Nevers, 2007). As such, the Standing NATO Maritime Group (SNMG, back then named STANAVFORMED) were deployed in the basin for monitoring and surveillance operations.

The OAE was initiated to support the United States with two aims. The first was, to detect any suspicious act of terrorist in the maritime domain, and to respond immediately to deter and disrupt terrorist activity. In the pursuit of securing the safety of the trade route, OAE focused on its focal point, which included detering, defending, disrupting and protecting the sea from any terrorist activities. Following the focal point of the OAE mandate, this operation can be classified into four significant elements: (a) to monitor shipping and trade routes, tracking and controlling suspected vessels; (b) to systematically carry out preparatory route surveys in 'choke' points area, important passage and ports; (c) to protect the safety of shipping including escorting vessels and navigating in the Straits of Gibraltar; and (d) to enhance the Alliance's security cooperation programme through OAE's mission (Calleya, 2013).

According to Calleya (2013), the aim of OAE and its current functions was listed as six main tasks as follows. Firstly, OAE mainly focused on surveillance activities, monitoring and tracking ships to detect any suspicious movements of vessels at sea, particularly in the Straits of Gibraltar. Secondly, OAE provided escorting assistance for those vessels requesting it from NATO ships. Thirdly, OAE hailed merchant vessels and boarded suspected ships with the compliance of the ships' masters and flag states. Next, OAE enabled NATO to strengthen training and exercises with its partner countries, including tactical navigation exercises to improve readiness to fight potential terrorist attacks. Moreover, OAE promoted closer cooperation with its partners in the Mediterranean Dialogue, in which the interested partners cooperated and contributed in the conduct of OAE in the Mediterranean Sea including through maritime surveillance. Finally, OAE also provided humanitarian assistance and support for important events in the international waters of the Mediterranean Sea.

\section{Surveillance, Monitoring and Tracking}

Since its first operation in October 2001, OAE under its purview has continually focused to deter, deny, disrupt and protect shipping activities from terrorist activities. OAE also intended 
to secure the safety of the Mediterranean Sea as one of the busiest trade routes in the world. In order to detect and deter terrorist attacks, NATO naval units carried out regular route surveys particularly in the important passage and 'choke' points navigated by thousands of merchant vessels daily. The presence of NATO ships operating under this operation led to a sharp decrease in terrorist movements in the eastern Mediterranean Sea. Consequently, the remit of this operation was expanded to encompass the entire Mediterranean Sea after the success of its previous operation.

Furthermore, this extension of coverage was also due to the growing fear that a terrorist group, Al-Qaeda, may launch its attacks in the Mediterranean following the attacks on the Limburg in 2002. The Straits of Gibraltar is the main focal point for terrorist attacks due to its status as the most busiest waterways in the world with approximately 300 vessels crossing the straits every day (Nevers, 2007). In 2002, the straits were claimed as a target of Al-Qaeda who were plotting an attack on American and British naval ships transiting the straits. Moroccan authorities, however, successfully obstructed the attempt as a result of regular surveillance in the straits. In addition, the Moroccan authorities also arrested several people believed to have a connection with the Al-Qaeda plot (The Guardian, 2002). Following the success, the task of this operation has been extended with additional mandates including compliant boarding and escorting assistance.

\section{Escorting Assistance}

Escorting merchant vessels has become a significant extension of the existing OAE after the success of its surveillance activities in the Straits of Gibraltar. In 2003, NATO naval ships operating under OAE began escorting vessels travelling through the Straits of Gibraltar for the Allied civilian ships which requested it. The NATO escort was conducted with support from the Allied partners, including the US and the Portuguese maritime patrol aircraft and helicopters. Under this operation, the NATO air and naval forces have been carrying out a great number of escorting operations for civilian vessels to protect them from terrorist activities.

Concurrently, NATO's Operation Straits of Gibraltar (STROG) was set up to continually assist OAE with maritime patrolling in the straits. STROG was designed to controlling and monitoring the western area of the Mediterranean Sea, in particular the movement of the vessel's entry in the area (Alexander, 2006). The Straits of Gibraltar is an important naval choke point which serves as a strategic access point to the Mediterranean Sea. The straits receives a huge volume of maritime traffic every year including merchant vessels and tankers carrying millions of barrels of oil. For escorting assistance, OAE is supported with naval assets by NATO members. Apart from that, the development in OAE was it included also non-NATO nations in the operation, including Morocco, Egypt and Tunisia (Ronzitti, 2012). According to the NATO Maritime Command in Northwood (UK), more than 100,000 vessels were hailed, and more than 488 merchant vessels escorted during the course of the operation (Fink, 2018). 


\section{Compliant Boarding}

Apart from surveillance and escort operations at sea, OAE has moved to include compliant boarding and inspection of suspicious vessels under NATO is efforts against terrorism. For this operation, merchant vessels passing through the Mediterranean Sea were hailed by patrolling NATO naval units if they were suspected of any unusual acts at sea. From April 2003, NATO ships have been carrying out systematic boarding on suspicious vessels in the eastern Mediterranean Sea. When NATO patrolling units discover any irregular movements at sea, the merchant vessels will be hailed and required to identify themselves and their identity. Should anything appear suspicious, the vessels will be boarded by the NATO crews to further inspect the documentation and cargo. For this practice, compliant boarding could only take place with the consent of the ship's master and flag state. The procedures of the boarding should also be in compliance with international law. During the boarding and inspection, a team of between 15 to 20 specially trained crew of NATO will be deployed onboard the vessel for further inspection, particularly for documentation purposes (Koknar, 2005). During the course of the operation, 155 vessels were boarded and consequently succeeded in deterring any potential terrorist attacks in the Mediterranean Sea (Fink, 2018).

\section{Joint Training and Exercises}

Next, the mandate of OAE is also to include training and naval exercises between NATO patrolling naval units and major regional partners in the Mediterranean. These partners include, among others, Italy, Morocco and Spain. Apart from conducting active boarding and escorting, NATO naval assets also extensively conducted joint-trainings and exercises, other than regular port visits between its Mediterranean partners (Cesaretti, 2009). The jointtraining and exercises are intended to increase the interaction and interoperability between NATO coastguard ships and the naval forces of its Mediterranean partners. During the course of the operation, NATO vessels will make a scheduled port visit to its partners in promoting intensive exchange of information and intelligence of counter-terrorism measures.

In addition, the port visit also aimed to improve data exchange on tactical navigation and technology- sharing to enhance processes of cooperation. With this extension of cooperation, the port visit has allowed NATO to build strong links with its important partners in conducting maritime operations in the Mediterranean Sea. This has consequently allowed NATO to exploit all means to accelerate the activation of the naval forces of its partners to intercept threats at sea under the remit of OAE. For regular port visits and joint-exercises with the Mediterranean partners, NATO has deployed the Standing NATO Maritime Group (SNMG 2) to support this operation (Cesaretti, 2009). This operation has achieved significant improvement between NATO and its Mediterranean partners' interoperability to further enhance the efficiency of maritime operations in fighting terrorist attacks at sea.

\section{Establishing Closer Links with the Mediterranean Dialogue Partners}

Under OAE, NATO is able to expand cooperation and establish closer links with its Mediterranean Dialogue partners. In 2004 during the NATO Summit in Istanbul, 
NATO expressed its desire to substantially improve cooperation and participation with the Mediterranean Dialogue partners through the maritime operations of OAE in the Mediterranean Sea (Cesaretti, 2008). As such, NATO welcomed any Mediterranean Dialogue partners who were interested to contribute in the OAE mission to also participate during the operation of OAE, including surveillance and escorting assistance. During the summit, several Mediterranean Dialogue countries (such as Israel, Morocco, Ukraine, Russia and Algeria) expressed their interest to participate in OAE,. Through this cooperation, the partners involved in OAE commenced operational cooperation by developing regular contact and data exchange. The patrolling naval assets of the partners would provide information and report to NATO vessels about any unusual shipping operations within their territorial waters. Following the report, NATO naval forces under OAE will take immediate action to detect and deter any potential terrorist threat in the Mediterranean Sea.

\section{Humanitarian Assistance and Support for Important Events}

Finally, the task of OAE encompasses the additional mandate to offer protection from terrorist attacks at sea, including providing humanitarian assistance for any emergencies at sea and support for important events upon request from NATO partners. More than 30 events have taken the opportunity from these operations including during the Athens Olympics in Greece and NATO's Istanbul Summit in 2004. Such events were highly visible and consequently exposed them to possible terrorist attacks from the terrorist groups who sought to garner attention during the international events. To show support for such important events, NATO ships and helicopters were deployed to conduct surveillance activities throughout the events in order to safeguard security and safety in the Mediterranean Sea. During the Athens Olympics in 2004, NATO naval forces, under OAE, provided assistance to the Greek government with early warning aircraft (AWACS) which were used to monitor air traffic and movements at sea. In addition, NATO coast, guards were also deployed in international waters around the Greek peninsula to conduct maritime patrol with the support and coordination from Greek coastguards.

Moreover, OAE has also acquired unexpected benefits with their presence at sea. Apart from providing monitoring assistance to combat terrorism, OAE has been successfully involved in a broad range of humanitarian assistance during emergency situations in the Mediterranean Sea. NATO ships and helicopters had intervened in several situations including search and rescue and disaster relief. These included rescuing civilians in emergency situations such as from sinking ships and stricken oil rigs. In January 2002, OAE significantly contributed in saving the lives of the refugees in a sinking ship in the eastern Mediterranean off Crete (Cesaretti, 2009).

\section{Conclusion}

Thousands of ships cross the Mediterranean Sea every day through several important choke points such as the Suez Canal and the Straits of Gibraltar. This has exposed the basin to massive possibilities of terror attacks that cannot be discounted. Although the number of 
terrorist attacks at sea remain lower than the attacks reported on land-based attacks, the international community could not underestimate the real terrorist threat faced by the vessels at sea. Previous atrocious attacks at sea such as Achille Lauro and Limburg demonstrated terrorist groups, capabilities to launch attacks on vessels at sea and consequently jeopardize the safety and security of maritime traffic and shipping. In recent years, the emergence of Islamic State extremists in the maritime realm has been a wakeup call for the international community that the states are now confronted with a real threat of terror at sea.

OAE was launched in the aftermath of the 9/11 terrorist attacks in the US as one of the eight initiatives in response to fight against international terrorism. The operation began its task with the main mandate to monitor and provide surveillance assistance for vessel movements in the entire Mediterranean Sea. OAE demonstrated NATO's coherence and resolve in the fight against terrorism with expanded maritime security cooperation with numerous NATO partners, especially those participating in the Mediterranean Dialogue. OAE has achieved substantial improvement in NATO's and its partners, cooperation, which has resulted in significant success in maintaining the security of the Mediterranean Sea from terrorist activities.

During the course of the operation, OAE has successfully detected, boarded, and intercepted hundreds of suspicious vessels which might have had connections with terrorist organizations. Apart from that, OAE has also escorted hundreds of merchant vessels while traversing the Straits of Gibraltar in order to protect them from possible terrorist attacks. In addition to tracking and patrolling suspect vessels, the continuous presence of NATO naval forces in the Mediterranean Sea also helped with disaster relief and emergency situations, and provided assistance for high visibility events against the threat of terrorism. OAE has played a vital role in the effort to fight terrorism at sea. OAE has continually enhanced the cooperation with its partners and increased extensive operations at sea. As a result, no terrorist plot has been detected in the Mediterranean since the beginning of the operation. Early detection of potential terrorist attacks in the Mediterranean has significantly helped to disrupt any attempt to attack the merchant vessels crossing the sea. In sum, the presence of NATO has favourably prevented terrorist activities in the Mediterranean Sea and simultaneously preserved the safety and security of the homelands of the Alliance and its partners.

\section{Acknowledgement}

This research received no specific grant from any funding agency in the public, commercial, or not-for profit sectors.

\section{References}

Acharya, A. (2007). Maritime terrorism threat in Southeast Asia. In Guan, K.C and Skogan, J. K. (Eds.)., Maritime Security in Southeast Asia (pp. 78-94). New York: Routledge. 
Alderwick, J., \& Giegerich, B. (2010). Navigating troubled waters: NATO's maritime strategy. Survival, 52(4), 13-20.

Alexander, Y. (2006). Counterterrorism strategies: Successes and failures of six nations. Washington: Potomac Books Inc.

Alexander, Y., \& Prosen, R. (2015). NATO: From regional to global security provider. London: Lexington Books.

Alexander, Y., \& Richardson, T.B. (2009). Terror on high seas: From piracy to strategic challenge. California: Praeger Security International.

Alsoudi, A. (2015). The impact of the Arab Spring on the political future of the Muslim Brotherhood in the Middle East: Jordan as a case study. Middle East Review of International Affairs, 19(3), 41-57.

Banlaoi, R. M. (2007). The Abu Sayyaf group: Threat of maritime piracy and terrorism. In Peter Lehr (Ed.), Violence at sea: Piracy in the age of global terrorism (pp. 121-138). New York: Routledge.

Batchelor, M. (2016). Libyan ISIS militants using migrant route across Mediterranean to reach Europe, warns MP. Retrieved from http://www.express.co.uk/news/ world/700176/Migrant-crisis-Islamic-State-fighters-reaching-Europe-refugeescrossing-Mediterranean

Bateman, S. (2006). Assessing the threat of maritime terrorism: Issues for the Asia-Pacific Region. Security Challenges, 2(3), 77-91.

Bateman, S. (2007). Outlook: The new threat of maritime terrorism. In Peter Lehr (Ed.), Violence at sea: Piracy in the age of global terrorism (pp. 241-258). New York: Routledge.

Bebler, A. (2008). NATO's role in the struggle against transnational terrorism. In Prezelj, I. (Ed.), The fight against terrorism and crisis management in the Western Balkans (pp. 3-15). Amsterdam: IOS Press.

Calleya, S.C. (2013). Security challenges in the Euro-Med area in the 21st century: Mare Nostrum. London: Routledge.

Fink, M. (2018). Maritime interception and the law of naval operations: A study of legal bases and legal regimes in maritime interception operations. Netherlands: Springer.

Joubert, L. (2013). The extent of maritime terrorism and piracy: A comparative analysis. South African Journal of Military Studies, 41(1), 111-137.

Krause, J., \& Bruns, S. (2016). Routledge handbook of naval strategy and security. New York: Routledge.

Marlow, P. B. (2010). Maritime security: An update of key issues. Maritime Policy and Management, 37(7), 667-676.

Martino, P. (2015). ISIS sets sights on the Mediterranean. Retrieved from http://www. gatestoneinstitute.org/5301/islamic-state-libya

Nevers, R. (2007). NATO's international security role in the terrorist era. International Security, 31(4), 34-66.

Nightingale, S. (2015). Islamic State Militants claim Egypt coastguard attack. Retrieved from http://www.ihsmaritime360.com/article/18696/islamic-state-militants-claimegypt-coastguard-attack 
Nincic, D. (2012). Maritime terrorism: How real is the threat? Retrieved from https://www. fairobserver.com/region/north america/maritime-terrorism-how-real-threat/

The Guardian. (2002). Al-Qaida cell planned Gibraltar Attacks: MI6 hunts terror plot network. Retrieved from http://www.theguardian.com/uk/2002/jun/12/september11. world 